\title{
THE PRESENT OF THE RACE AND ETHNICITY THEME IN A STUDY ON THE DISAFRICANIZATION OF ANCIENT EGYPT
}

Raisa Sagredo ${ }^{1}$

Defended at the beginning of 2017 in the Graduate Program in History of the Federal University of Santa Catarina, the Master's dissertation entitled Race and Ethnicity: questions and debates around the disafricanization of Ancient Egypt, brought to the fore reflections of long date, coupled with intense current debates on the issue. Guided by the African expert of the Department, Prof. Dr. Sílvio Marcus de Souza Correa, the dissertation was proposed to make an analysis of the disafricanization phenomenon of Ancient Egypt within historiography and Egyptology. The theme, even though for some it may seem to have already been surpassed, it is still today an teeming area for disputes of postcolonial identities and wounds, where a "race" category is appropriated by discourses that defend whiteness and blackness of the ancient Egyptians. Far from being a recent problematic, the so-called misapprehension of Egypt starts with the process where Egypt is pulled out from the African universe by Eurocentrism and Orientalism, making it arbitrarily related geographically, anthropologically and culturally to only Western Asia and to the Mediterranean world. "White" Egypt was already refuted by Volney, an eighteenth-century traveler, Firmin, and Douglass, an American intellectual and former US slave in the nineteenth century, gaining greater visibility in the Pan-Africanist movement and its claims against racism.

With the studies of the Senegalese Egyptologist Cheikh Anta Diop in the early twentieth is that the so-called blackness of the ancient Egyptians was systematized and researched within the sciences, being a legacy that remains through the so-called Kemetic Afrocentrism. ${ }^{2}$ This, coexists with a hegemonic memory of an Egypt displaced from Africa and whitened,

\footnotetext{
1 M.A. in History, Federal University of Santa Catarina, Curitiba, Brazil. E-mail: nefertitisagredo@gmail.com

2 The term Kemetic Afrocentrism is so named because of one of Diop's theses, where the term kemet or kemit - transcription of the word kmt - would be translated as "black" or "black men", according to Diop.
} 
one which is perceived and perpetuated through the imaginary and most representations of the pharaonic past.

By historicizing the question, one can see how the racialization of Egypt's historiography directly and indirectly implicates the questions posed to its past, and how it shaped the ways of conceiving the same, referring, therefore, to the nineteenth-century racial theories and to the very construction of a knowledge, the Egyptology. It also aims to conceive how debates about ethnicity can be an interesting strategy in such polarized discussions. More specifically in respect to Pharaonic Egypt, these studies have been done for some decades, nevertheless, the problematization of binarism is still necessary, once as analyzed in the bibliography, racial debates are still intense. From reading on postcolonial, decolonial, in dialogue with Anthropology, it is possible to question the pertinence of key categories used in this disafricanization, from its concepts to its use within Ancient History - such as the concept of race. Therefore, it seems possible to understand the subjectivity of the processes that led socially to the misapprehension of Egypt, proposing a critical balance that reflects on the epistemological and historiographic consequences of the different approaches.

What the dissertation brings of novelty is the proposal to historicize the binarism present in the discourses on disafricanization of Egypt, proposing precisely to break the logic of racialization, introducing the existing studies on ethnicity in antiquity and dialoguing with Brazilian contributions to the question. How did the racial question resonate in Brazil in terms of Egyptology? How can the example of black Egypt claimed by the Olodum and Brazilian carnival movements help to understand how Afrocentrism had reverberated in the country? Hence the importance of realizing how this racialization was being built and systematically introduced in Ancient History, with a critical assessment of a vast bibliography.

The research also used contributions from postcolonial archeology, dialogues with decolonial thinkers, built up from Barth, and contemporary discussions, new research on Nubia and the new look at a memory that was previously so subalternized for so many centuries were included. This way, it's possible to help to break cultural and racial unidirectional and hierarchical approaches. Exemplifying the timeliness of such unidirectional claims, a recent bibliography has been brought to the attention from the so-called African Egyptology and its main current exponents, Obenga and Asante. The American critique to Kemetic Afrocentrism (Lefkowitz, Montellano, Moses, Walker), the French criticism (Henry Tourneaux et al.), and criticisms from African 
intellectuals such as Mbembe and Appiah about African identity and racialization in Africa were inserted.

The attention to the subalternizations present in both perspectives equally in the Afrocentric and in their critique - and, mutatis mutandis with respect to the weight and conception of race contained in both, the perspective of ethnicities does not deny or ignore previous appreciations. I think that as discussions on Egyptian antiquity ethnicity are part of this movement. This challenge directly dialogues with the debates within the Brazilian scenario on racial issues as well within the teaching of History of Africa and the Law 10.632.

In the context of the current discussions on Global History, this dissertation constitutes a further effort to think, as Costa e Silva argues, an Ancient Egypt located at the corner of the Ancient World (2006), conceiving and remembering an Egypt beyond its African geography, which contributes highly to historiography, Egyptology and to the debates about the Africanization of Egypt. Together, these three aspects can add to the deconstruction of the idea of the center and the periphery, displayed both within Eurocentrism and Kemetic Afrocentrism. 